\title{
Consequences of two common techniques for sampling vagile macrofauna associated with the seagrass Zostera capricorni
}

\author{
Charles A. Gray ${ }^{1,2}$ \& Johann D. Bell ${ }^{1,3}$ \\ ${ }^{1}$ Division of Fisheries, New South Wales Department of Agriculture, P.O. Box K220, Haymarket, N.S.W. 2000, Australia \\ ${ }^{2}$ Department of Zoology, School of Biological Sciences, University of Sydney, Sydney, N.S.W. 2006, Australia \\ ${ }^{3}$ School of Biological Sciences, Macquarie University, North Ryde, N.S.W. 2113 , Australia*
}

\begin{abstract}
Fish and decapod crustaceans associated with the seagrass Zostera capricorni Aschers were sampled by beam trawling during the day, beam trawling at night and poisoning during the day There were significant differences in the numbers of species and individuals sampled by each method. Beam trawling during the day captured $30 \%$ fewer species of fish than did either night trawling or poisoning. However, day trawls caught $85 \%$ fewer and night trawls caught $60 \%$ fewer individuals of fish than poisoning. Poisoning and day trawling, respectively, caught 46 and $40 \%$ fewer species, and 82 and $48 \%$ fewer individuals, of decapods than beam trawling at night. Consequently, species composition of samples also differed between methods. Our data suggest that more serious consideration should be given to the reliability of different techniques for sampling the vagile macrofauna of seagrass meadows
\end{abstract}

\section{INTRODUCTION}

Two sampling methods dominate studies of fish and decapods associated with seagrass: trawling (e.g. Heck 1977, 1979, Weinstein \& Heck 1979, Heck \& Orth 1980 Young 1981, Bell \& Harmelin-Vivien 1982) and poisoning with rotenone (e.g. Bell et al. 1978, Martin \& Cooper 1981, Weinstein \& Brooks 1983, Burchmore et al. 1984, Middleton et al. 1984). Both methods are selective. Mesh selectivity and avoidance of nets are problems associated with trawling (Kjelson \& Colby 1977), whereas rotenone affects species differently, depending on its concentration and the prevailing environmental conditions (Schnick 1974).

Despite this knowledge, little attention has been given to the effects of different sampling techniques when describing species composition of vagile macrofauna in seagrass meadows. This is an important oversight. Variation in the composition of assemblages of fish associated with seagrasses may reflect sampling technique. In his review of seagrass fishes, Pollard (1984) found that a sample of fish collected from an

\footnotetext{
- Address for reprint requests (to J. D. Bell)
}

estuary with rotenone was more similar to one collected using the same technique from another (adjacent) estuary than to an assemblage from the same estuary (same meadow) sampled with a beam trawl. Collett et al. (1984), however, found that when the same sampling technique is used, samples of invertebrates from different meadows within an estuary were more similar to one another than to those from other estuaries.

Weinstein \& Brooks (1983) and Middleton et al. (1984) are among the few workers who have used both trawling and poisoning techniques during a single study. Unfortunately, comparisons between the effectiveness of each technique are not possible from their work. In both studies, the sizes of areas sampled and the mesh size of nets used differed considerably between techniques.

Because the consequences of using poison or trawling are unknown, comparisons between faunas collected using different methods (e.g. Harmelin-Vivien 1983, Pollard 1984) remain difficult to interpret. Here we investigate differences in samples of vagile macrofauna associated with the seagrass Zostera capricorni Aschers. collected by 3 methods: beam trawling 
during the day, beam trawling at night and poisoning during the day. We addressed the following questions: (1) Do these techniques capture comparable numbers of species and individuals? (2) Do the techniques sample similar species? (3) Are some species sampled more effectively with a particular method?

\section{MATERIALS AND METHODS}

Study area. We used a subtidal portion of a 10 ha Zostera capricorni meadow in Careel Bay, Pittwater, New South Wales $\left(33^{\circ} 37^{\prime} \mathrm{S}, 151^{\circ} 17^{\prime} \mathrm{E}\right)$ for this study. Our sampling sites were all within a $70 \times 7 \mathrm{~m}$ belt of seagrass. This belt was sited parallel to the edge of the meadow to eliminate edge effects (Orth 1977). All sites had a depth of $0.3 \mathrm{~m}$ at low tide.

Description of techniques: Trawling. We used a beam trawl similar to that used by Young (1981) except that ours had a chain instead of a roller at the foot of the net. The net was $1 \mathrm{~m}$ wide with $2 \mathrm{~mm}$ mesh in the body and $1 \mathrm{~mm}$ mesh in the cod end. The net was pulled by hand at a constant speed over a $9 \mathrm{~m}$ strip of Zostera.

Poisoning. This technique was developed from the methods of Bell et al. (1978). A wall net with $1 \mathrm{~mm}$ mesh and a depth of $2 \mathrm{~m}$ was placed around the perimeter of an area measuring $6 \times 6 \mathrm{~m}$. Another net, in the form of a cross, was used to divide the area into four $3 \times 3 \mathrm{~m}$ plots. Half a litre of fish poison $(5 \%$ rotenone concentrate) was applied to the substratum in each plot. Fauna were collected from the surface with dip nets and then by searching the substrate and seagrass canopy thoroughly using diving equipment. Disturbances to vagile macrofauna when these nets are installed are negligible (Bell \& Westoby unpubl.). Collection from 4 adjacent plots simultaneously rather than 4 separate samples minimised contamination of surrounding areas by poison. It is also 4 times as fast. an important consideration when controlling for the effects of tide. For these reasons the 4 plots were used as replicates in this study, although they are not strictly independent of each other

Experimental design. We collected eight $9 \mathrm{~m}^{2}$ replicates using each method. We used the beam trawl during the day on 24 January 1984 and again that night. Poisoning was done the next day to avoid contaminating areas used for trawling. We did not use poison at night because fauna could not be collected from the substratum. We used each method 1 to $2 \mathrm{~h}$ from low tide when the depth of water was 0.5 to $0.8 \mathrm{~m}$. Sites used for poisoning were situated at the 2 ends of the sampling area, so that the first poison sample did not contaminate the area used for the second. We divided the area in between into 4 sections. Four repli- cate trawls were made during the day in Sections 1 and 3 , and 4 replicates were sampled in Sections 2 and 4 during the night. Replicate trawls were on adjacent but non-overlapping strips of seagrass.

The height and/or density of Zostera capricorni influences the abundances of several macrofaunal species associated with it (Bell \& Westoby unpubl.). Therefore we chose sites which seemed to have similar leaves. After sampling we counted the number of shoots in 8 randomly placed $20 \times 20 \mathrm{~cm}$ quadrats and measured 100 leaves picked at random from each site. Density of shoots did not differ significantly between sites (1-way ANOVA, $p>0.05$ ) but areas used for day trawls had significantly longer leaves than those for night trawls and poisoning (1-way ANOVA, $p<0.05$, Student-Newman-Keuls [SNK] test).

\section{RESULTS}

\section{Differences in numbers of species and individuals}

Most species were caught by trawling at night whereas fewest were caught by trawling during the day (Table 1). There were no significant differences between the numbers of species of fish caught by

Table 1. Mean number of species and individuals in day trawls, night trawls and poison samples. Significance levels derived from 1-way ANOVA $(\mathrm{df} 2,21)$ of $\ln (\mathrm{x}+1)$ transformed data. Results of Student-Newman-Keuls (SNK) test indicates which means differ; means joined by a line are not significantly different

\begin{tabular}{|c|c|c|c|c|c|}
\hline Variable & $\begin{array}{c}\text { Day } \\
\text { trawl } \\
\text { (D) }\end{array}$ & $\begin{array}{c}\text { Night } \\
\text { trawl } \\
(\mathrm{N})\end{array}$ & $\begin{array}{l}\text { Poi- } \\
\text { son } \\
\text { (P) }\end{array}$ & $\begin{array}{l}\text { Sig- } \\
\text { nifi- } \\
\text { cance }\end{array}$ & SNK \\
\hline No. species of fish & 5.0 & 6.8 & 7.5 & $\cdot$ & DNP \\
\hline No. individuals of fish & 6.6 & 17.1 & 44.1 & $\cdots$ & $D \overline{N P}$ \\
\hline No. species of decapods & 4.4 & 8.5 & 4.8 & $\cdots$ & $\underline{D P} N$ \\
\hline $\begin{array}{l}\text { No. individuals of } \\
\text { decapods }\end{array}$ & 60.4 & 116.1 & 20.9 & $\cdots$ & PDN \\
\hline Total no. species & 9.4 & 15.3 & 12.3 & $\cdots$ & DPN \\
\hline Total no. individuals & 67.0 & 133.3 & 65.0 & $\cdots$ & $\underline{D P N}$ \\
\hline \multicolumn{6}{|c|}{$\begin{aligned} & \text { Significance: } \quad . \quad p<0.05 \\
& \ldots p<0.001\end{aligned}$} \\
\hline
\end{tabular}

poisoning and by trawling, but significantly more species of decapods were caught trawling at night than by the other methods. Similar trends occurred for differences in the total number of individuals taken by each method (Table 1) 
Table 2. Mean abundances of common species of fish and decapods in day trawls, night trawls and poison samples. Significance levels derived from 1-way ANOVA (df 2,21) of $\ln (x+1)$ transformed data, except when a species was only collected by 1 method, in which case a t-test was used. Means joined by a line are not significantly different using SNK tests

\begin{tabular}{|c|c|c|c|c|c|}
\hline $\begin{array}{l}\text { Family } \\
\text { Species }\end{array}$ & $\begin{array}{l}\text { Day trawl } \\
\text { (D) }\end{array}$ & $\begin{array}{l}\text { Night trawl } \\
(\mathrm{N})\end{array}$ & $\begin{array}{l}\text { Poison } \\
\text { (P) }\end{array}$ & Significance & SNK \\
\hline \multicolumn{6}{|l|}{ FISHES } \\
\hline \multicolumn{6}{|l|}{ Syngnathidae } \\
\hline Syngnathus margaritifer & 0.8 & 1.6 & 0.1 & $\cdot$ & \multirow[t]{2}{*}{$\underline{P D N}$} \\
\hline Urocampus carinirostris & 0.3 & 1.0 & 0.0 & ns & \\
\hline \multicolumn{6}{|l|}{ Scorpaenidae } \\
\hline Centropogon australis & 1.0 & 1.4 & 0.5 & ns & \\
\hline \multicolumn{6}{|l|}{ Teraponidae } \\
\hline Pelates sexlineatus & 1.9 & 7.5 & 12.5 & $\cdots$ & D N P \\
\hline \multicolumn{6}{|l|}{ Sparidae } \\
\hline Rhabdosargus sarba & 0.1 & 0.4 & 1.4 & $\cdots$ & $\underline{D N P}$ \\
\hline \multicolumn{6}{|l|}{ Gobiidae } \\
\hline Bathygobius kreffti & 0.8 & 1.9 & 6.8 & $\cdots$ & D N P \\
\hline Arenigobius frenatus & 0.4 & 0.8 & 18.1 & $\cdots$ & $D N P$ \\
\hline Cryptocentroides cristatus & 0.0 & 0.0 & 1.4 & $\cdot$ & $\overline{\mathrm{DN}} \mathrm{P}$ \\
\hline \multicolumn{6}{|l|}{ DECAPODS } \\
\hline \multicolumn{6}{|l|}{ Penaeidae } \\
\hline Penaeus plebejus & 0.5 & 7.8 & 1.5 & $\cdots$ & $\underline{P D N}$ \\
\hline \multicolumn{6}{|l|}{ Palaemonidae } \\
\hline Macrobrachium intermedium & 49.6 & 72.6 & 1.8 & $\cdots$ & P D N \\
\hline \multicolumn{6}{|l|}{ Alpheidae } \\
\hline Alpheus pacificus & 0.0 & 3.1 & 14.1 & $\cdots$ & D N P \\
\hline Alpheus leviusculus & 0.0 & 0.0 & 1.9 & $\cdot$ & $\underline{D N P}$ \\
\hline \multicolumn{6}{|l|}{ Hippolytidae } \\
\hline Periclimenes (P.) obscurus & 4.8 & 24.4 & 0.0 & $\cdots$ & PD N \\
\hline Latreutes of. porcinus & 4.4 & 3.1 & 0.0 & $\cdots$ & PDN \\
\hline Hippolyte caradina & 0.5 & 1.3 & 0.0 & $\cdot$ & $\underline{\mathrm{PDN}}$ \\
\hline $\begin{aligned} \text { Significance: } & \text { ns } \quad \text { Not significant } \\
& \cdots p<0.05 \\
& \quad p<0.001\end{aligned}$ & & & & & \\
\hline
\end{tabular}

\section{Differences in species composition}

A total of 37 species was collected: 20 in day trawls, 30 in night trawls, and 23 in poison samples. One species was unique to day trawls, 5 to night trawls and 6 to poison: 25 species were caught by 2 or more methods. Six of the 15 common (i.e. mean $>1$ in any method) species in the assemblage were captured only by the trawl or by poison (Table 2). Differences in species composition of samples were more pronounced when their similarities were compared. A Principal Co-ordinates Analysis (Williams 1976) removed $63 \%$ of the variance on Axes I and II. It completely separated poison samples from trawl samples on Axis I (Fig. 1). Eight of the 12 species correlated with Axis I at $p<$ 0.05 were present only from trawl or poison samples (Table 3). Thus Axis I represents sampling technique at

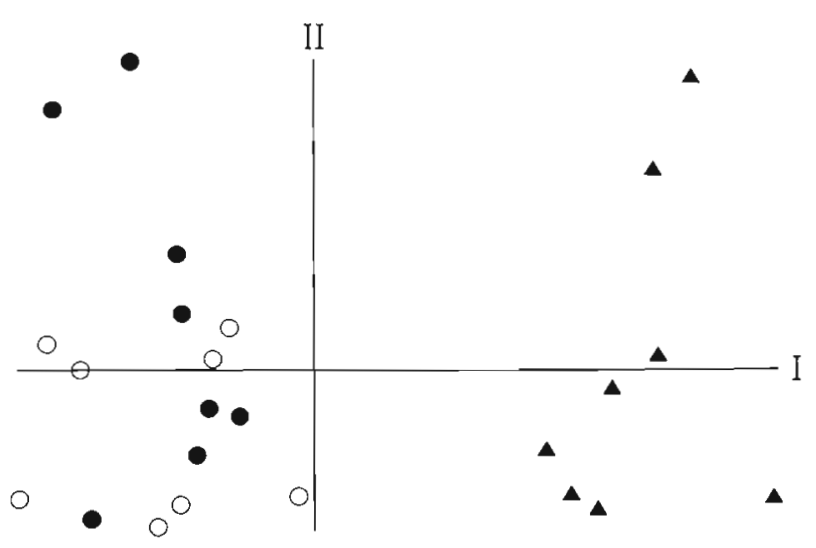

Fig. 1. Principal Co-ordinates Analysis of presence/absence data for samples collected by (O) day trawling, ( $\bullet$ ) night trawling and $(\Delta)$ poisoning 
Table 3. Species significantly correlated $(p<0.05)$ with Axes I and II in the Principal Co-ordinates Analysis, the method(s) which captured them and their daytime living position. DT = day trawl; NT = night trawl; $\mathrm{P}=$ poison; $\mathrm{B}=$ benthic; $\mathrm{C}=$ seagrass canopy; $W=$ water column. Where a species was sampled by more than 1 method, the method by which most were caught is underlined

\begin{tabular}{|c|c|c|c|c|}
\hline Species & $\begin{array}{l}\text { Correlation } \\
\text { co-efficient } \\
\text { with Axis I }\end{array}$ & $\begin{array}{l}\text { Correlation } \\
\text { co-efficient } \\
\text { with Axis II }\end{array}$ & $\begin{array}{l}\text { Capture } \\
\text { technique }\end{array}$ & $\begin{array}{c}\text { Daytime living } \\
\text { position }\end{array}$ \\
\hline Periclimenes (P.) obscurus & 0.95 & & $\mathrm{DT}, \underline{\mathrm{NT}}$ & $\mathrm{C}$ \\
\hline Latreutes cf. porcinus & 0.86 & & $\mathrm{DT}, \overline{\mathrm{NT}}$ & $\mathrm{C}$ \\
\hline Alpheus leviusculus & 0.82 & & $\mathrm{P}-$ & $\mathrm{B}$ \\
\hline Ophisurus serpens & 0.77 & & $P$ & $\mathrm{~B}$ \\
\hline Cryptocentroides cristatus & 0.76 & & $\mathrm{P}$ & B \\
\hline Rhabdosargus sarba & 0.75 & & $\mathrm{DT}, \mathrm{NT}, \underline{\mathrm{P}}$ & W \\
\hline Arenigobius frenatus & 0.75 & & DT, NT, $\underline{\bar{p}}$ & B \\
\hline Cristiceps australis & 0.58 & & $\mathrm{DT}, \underline{\mathrm{NT}}{ }^{-}$ & C \\
\hline Callianassa australiense & 0.57 & & $\mathrm{P}-$ & $\mathrm{B}$ \\
\hline Hippolyte caradina & 0.53 & & DT, NT & $\mathrm{C}$ \\
\hline Syngnathus margaritifer & 0.49 & & $\mathrm{DT}, \overline{\mathrm{NT}}, \mathrm{P}$ & $\mathrm{C}$ \\
\hline Alpheus pacificus & 0.48 & & $N T, \bar{p}$ & $\mathrm{~B}$ \\
\hline Cnidoglanis macrocephalus & & 0.79 & NT, $\overline{\underline{P}}$ & $\mathrm{~B}$ \\
\hline Centropogon australis & & 0.69 & $\mathrm{DT}, \overline{\mathrm{N} T}, \mathrm{P}$ & $\mathrm{B}$ \\
\hline Stigmatopora argus & & 0.61 & $\mathrm{DT}, \overline{\mathrm{NT}}, \mathrm{P}$ & C \\
\hline Unidentified crab & & 0.46 & $\mathrm{DT}, \overline{\mathrm{NT}}, \mathrm{P}$ & B \\
\hline Sphyraena waitii & & 0.43 & $\mathrm{P}-$ & W \\
\hline Batrachomeus dubius & & 0.42 & $N T, \underline{P}$ & B \\
\hline Palaemon sp. & & 0.41 & DT,,$\underline{\mathrm{NT}}$ & $\mathrm{C}$ \\
\hline
\end{tabular}

a broad level (i.e. trawling vs poisoning). Mean Axis I scores from each method were significantly different (1-way ANOVA, $p<0.001$ ). Poison samples differed from all trawl samples but there were no significant differences between day and night trawls (SNK Test).

We have categorised species correlated with Axis I as benthic (living within or on the substratum), seagrass canopy, or water column dwellers (Table 3). Species correlated with Axis I and present only in poison samples were generally benthic whereas those found only in the trawl samples were canopy species.

The species composition of samples from day and night trawls separated to some degree on Axis II (Fig 1), although they were not significantly different $(\mathrm{t}=$ $1.70, p>0.05)$. The species in trawls that correlated well with Axis II were caught in greater abundance at night and were benthic or seagrass canopy species (Table 3)

\section{Effectiveness of methods of sampling common species}

The 3 methods did not collect the common species with the same efficiency (Table 2). All common species of fish except the Syngnathidae and Scorpaenidae were caught in greater numbers by poison. Trawling at night was the next most effective way of capturing these fish. In general, abundant decapods were collected best by the beam trawl, especially when used at night. Exceptions to this were the alpheid shrimps, which were more abundant in poison samples.

\section{DISCUSSION}

When we controlled for effects of sampling site, seagrass density, stage of tide, depth of water, mesh size of nets and sampling area we found significant differences in samples taken by trawling and poisoning. We could not eliminate the effects of height of seagrass leaves. Although abundances of some fish are significantly correlated with height of leaves (Bell \& Westoby unpubl.), this is of little importance here. Mean height of leaves was significantly greater at sites used for trawling during the day. Thus, despite the potential habitat 'enhancement' of these sites, significantly fewer fish were caught trawling during the day.

The most striking difference between methods was that more fish were caught by poisoning and more decapods were caught by trawling, especially at night. Most canopy dwelling fish can avoid the trawl and although the trawl we used was fitted with a chain, it sampled benthic fish species poorly. There were no infaunal fishes in trawl samples. This is a weakness of this method because, although such fishes (e.g. ophichthid eels) are not abundant, they are important predators of fish and decapods associated with seagrass (J. D. Bell unpubl.). 
Fig. 2. Penaeus plebejus. Carapace length frequency distributions of shrimp captured by the 3 methods

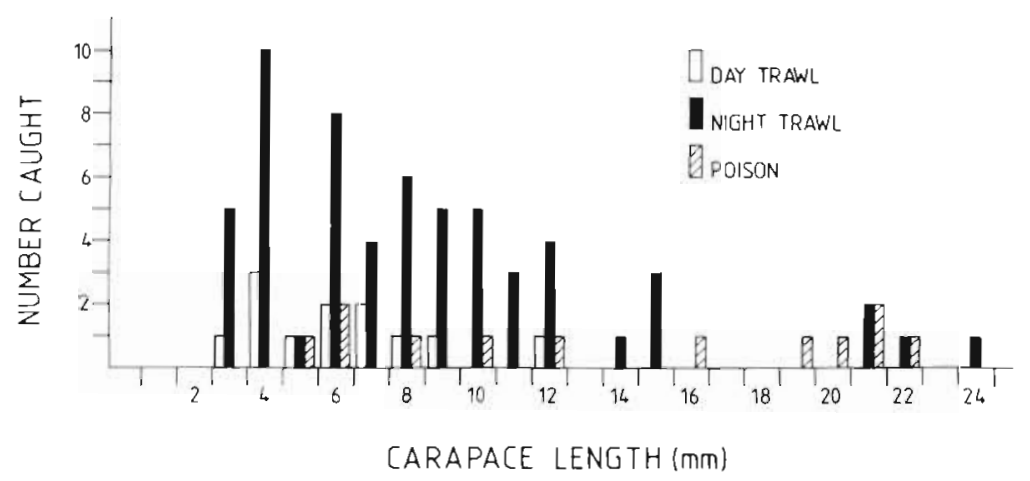

The decapods in the assemblage were either small or were mainly represented by juveniles. Except for the shrimp Penaeus plebejus Hesse and the alpheid shrimps, these species did not come to the surface when poisoned, but died in situ. Their small size and cryptic colouration made them very difficult to locate amongst the seagrass. However, more infaunal decapods, e.g. alpheid shrimps, were caught using poison. Such species do not climb amongst the foliage and so are rarely vulnerable to trawling. Thus, poisoning is only likely to be as effective as trawling in collecting large benthic decapod individuals, such as crabs, and infaunal species. Differences in the size selectivity of trawling and poisoning in sampling the decapods is evident from the length frequency distributions of $P$. plebejus (Fig. 2). This shrimp is inactive during the day but frequents the water column at night. Both trawling during the day and poisoning undersampled the smaller individuals

It is clear from the selectivity of techniques on common species and from the Principal Co-ordinates Analysis that total species composition is more thoroughly described when more than 1 technique is used. This is not however, always possible. Trawling is not suitable where the area of seagrass is small or of an irregular shape. Use of poison is labour intensive and often not practical where quantitative samples are needed from deep water, where large areas must be sampled, or when water is turbid. This last fact is important because up to $50 \%$ of individuals may not surface when poisoned and must be seen amongst the seagrass.

It should also be noted that rotenone is toxic to man if inhaled, swallowed or otherwise absorbed (Sax 1979) and must be used with caution. It is safe to use liquid rotenone provided that (1) clothes preventing contact with the skin, such as chest waders, are used when applying it to the substrate; and (2) fauna are not collected from the substrate with diving gear until all the poison has left the area. In practice, therefore, poisoning should be restricted to shallow sites with a slight tidal current.

When only trawling is possible, we see little need for trawling during the day. Few species were caught trawling during the day that were not caught at night. Fish in seagrass meadows are more susceptible to a trawl at night, either because they are asleep, or, in the case of nocturnally active species, because they leave shelter around the base of shoots to forage. Thus the shoots would no longer obstruct their capture by the trawl. Crustaceans in seagrasses are also more active at night (Ledoyer 1968, Heck 1979, Greening \& Livingston 1982). In meadows of Zostera capricorni, differences between day and night trawl samples do not indicate a diel change-over in species composition. Instead, day samples were a subset of an assemblage which is more vulnerable to being caught at night. This is not true of all seagrass habitats. For example, Bell \& Harmelin-Vivien (1982) and Robblee \& Zieman (1984) recorded nocturnal invasions of seagrass by fishes from other habitats. Sampling during the day and night is needed to detect the presence of such nocturnal invaders.

Our data indicate that different sampling methods produce significant differences in samples of fish and decapods associated with seagrass meadows. Because it is not possible to sample all vagile macrofauna with only 1 method, we advocate use of night trawling and day poisoning for seagrass studies aimed at describing the entire fish and decapod assemblage. Our data also suggest which technique is best for sampling a particular species or suite of species.

Acknowledgements. We thank A. Steffe for assistance with the collection and sorting of samples. $T$ Lau helped with the Principal Co-ordinates Analysis and J. Burchmore, S. Kennelly, D. Pollard, R. Williams and A. Underwood made useful suggestions which improved the draft manuscript.

\section{LITERATURE CITED}

Bell, J. D., Burchmore, J. J., Pollard, D. A. (1978). Feeding ecology of a scorpaenid fish, the fortescue Centropogon australis, from a Posidonia seagrass habitat in New South Wales. Aust. J. mar. Freshwat. Res. 29: 175-185

Bell, J. D., Harmelin-Vivien, M. L. (1982). Fish fauna of 
French Mediterrannean Posidonia oceanica seagrass meadows. 1. Community structure. Téthys 10: 337-347

Burchmore, J. J., Pollard, D. A., Bell. J. D. (1984). Community structure and trophic relationships of the fish fauna of an estuarine Posidonia australis seagrass habitat in Port Hacking, New South Wales. Aquat. Bot. 18: 71-87

Collett, L. C., Hutchings, P. A., Gibbs, P. J., Collins, A.J. (1984). A comparative study of the macro-benthic fauna of Posidonia australis seagrass meadows in New South Wales. Aquat. Bot. 18: 111-134

Greening, H. S., Livingston, R. J. (1982). Diel variation in the structure of seagrass-associated epibenthic macroinvertebrate communities. Mar Ecol. Prog. Ser 7: 147-156

Harmelin-Vivien, M. L. (1983). Etude comparative de l'ichtyofauna des herbiers de phanerogames marines en milieux tropical et tempere. Rev, Ecol. (Terre Vie) 38: $179-210$

Heck, K. L., Jr. (1977). Comparative species richness, composition and abundance of invertebrates in Caribbean seagrass (Thalassia testudinum) meadows (Panama). Mar Biol. 41: 335-348

Heck, K. L., Jr (1979). Some determinants of the composition and abundance of motile macroinvertebrate species in tropical and temperate turtlegrass (Thalassia testudinum) meadows. J. Biogeogr 6: 183-200

Heck, K. L., Jr., Orth, R. J. (1980). Structural components of eelgrass (Zostera marina) meadows in the lower Chesapeake Bay - Decapod crustacea. Estuaries 3: 289-295

Kjelson, M. A., Colby, D. R. (1977). The evaluation and use of gear efficiencies in the estimation of estuarine fish abundance. In: Wiley, M. (ed.) Estuarine processes, Vol 2. Academic press, New York, p. 416-424

Ledoyer, M. (1968). Ecologie de la fauna vagile des biotopes Mediterraneens. IV Synthese de l'etude ecologique. Recl. Trav. Stn. mar Endoume 44: 125-295

Martin, F. D., Cooper, M. (1981). A comparison of fish faunas found in pure stands of two tropical Atlantic seagrasses, Thalassia testudinum and Syringodium tiliforme. Northeast Gulf Sci. 5: 31-37

Middleton, M. J., Bell, J. D., Burchmore, J. J., Pollard, D. A., Pease, B. C. (1984). Structural differences in the fish communities of Zostera capricorniand Posidonıa australis seagrass meadows in Botany Bay, New South Wales. Aquat. Bot. 18: 89-109.

Orth, R. J. (1977). The importance of sediment stability in seagrass communities. In: Coull, B. (ed.) Ecology of marine benthos. University of South Carolina Press, Columbia, p. 281-300

Pollard, D. A. (1984). A review of ecological studies on seagrass fish communities, with particular reference to recent studies in Australia. Aquat. Bot. 18: 3-42.

Robblee, M. B., Ziemann, J. C. (1984). Diel variation in the fish fauna of a tropical seagrass feeding ground. Bull. mar. Sci. 34: 335-345

Sax, N. I. (1979). Dangerous properties of industrial materials. 5 th edn. Van Nostrand Reinhold, New York

Schnick, R. A. (1974). A review of the literature on the use of rotenone in fisheries. U.S. Dept. Fish and Wildlife, Washington, p. 1-129

Weinstein, M. P., Brooks, H. A. (1983). Comparative ecology of nekton residing in a tidal creek and adjacent seagrass meadow: community composition and structure. Mar. Ecol. Prog. Ser 12: 15-27

Weinstein, M. P., Heck, K. L., Jr (1979). Ichthyofauna of seagrass meadows along the Caribbean coast of Panama and in the Gulf of Mexico: composition, structure and community ecology. Mar. Biol. 50: 97-107

Williams, W. T (ed.) (1976). Pattern analysis in agricultural Science. C.S.I.R.O., Melbourne and Elsevier, Amsterdam

Young, P. C. (1981). Temporal changes in the vagile epibenthic fauna of two seagrass meadows (Zostera capricorni and Posidonia australis). Mar Ecol. Prog. Ser. 5: 91-102 